\title{
Comparative bone uptake study of alendronate sodium from vaginal suppositories prepared with polyethylene glycol and massa estarinum bases
}

\author{
Derya İlem-Özdemir¹, Kamil Köseoğlu², Makbule Aşıkoğlư1, Hayal Özkılıç², Tamer Güneri
}

\begin{abstract}
The aim of this study was to compare the bone uptake of alendronate sodium (ALD) from vaginal suppositories prepared with massa estarinum $A B(M E)$ and polyethylene glycol 1500 (PEG) bases. For this purpose, ALD was radiolabeled with 99mTecnetium Pertechnetate $(99 \mathrm{mTC})$ by direct method. Radiochemical purity and stability of $99 \mathrm{mTC}-\mathrm{ALD}$ was performed with chromatographic studies. ${ }^{99 m T C}$-ALD containing suppositories were prepared with ME and PEG bases. Physical properties of suppositories were evaluated. The physicochemical diffusion study was carried out to compare the release of ALD from different suppository bases. The bone uptake of $99 \mathrm{mTC}-\mathrm{ALD}$ was observed by gamma scintigraphy studies. $99 \mathrm{mTC}-A L D$ containing suppositories were administrated to rabbits via vaginal route. The scintigraphic images were obtained with a gamma camera at different time intervals up to 240 minutes. According to our studies, radiochemical purity of $99 \mathrm{mTC}-A L D$ was observed more than $95 \%$ up to 6 hours. At 240 minutes of physicochemical diffusion studies, released ALD has $0.620 \pm 0.091 \mathrm{~mm}$ and $10.465 \pm 0.651 \mathrm{~mm}$ diameter zone from ME and PEG base suppositories respectively. According to the gamma scintigraphy studies, although no bone uptake observed after ME suppositories application, rabbit's bones were clearly visible after PEG suppositories applied. The results of physicochemical diffusion and gamma scintigraphy studies were found compatible in each other.
\end{abstract}

KEY WORDS: Alendronate sodium, bone uptake, vaginal suppository, massa estarinum, polyethylene glycol

\section{INTRODUCTION}

Bisphosphonates are used in the management of various disorders affecting the skeleton, including osteoporosis, metastatic bone disease and $\mathrm{Pa}$ get's disease of bone. Bisphosphonates are selectively uptake at active bone sites, suppressed the osteoblast and osteoclast mediated bone resorption (1-4). Alendronate sodium (ALD) is a second generation amino bisphosphonates that selectively inhibits osteoclast-mediated bone resorption, increases bone mineral density and reduces the incidence of vertebral, hip and other fractures (5-7). Like all bisphosphonates, ALD is poorly absorbed from the gastrointestinal tract, with an oral bioavailability of around $0.9-1.8 \%$ (8). Its absorption is markedly reduced by food (9).
In recent years, there is a challenge for novel drug delivery systems to achieve improved bioavailability and safety. Various researchers have described new formulations to treat bone disease with minimal side effects and high efficiency. Because of the poor gastrointestinal absorption several administration routes have been attempted to enhance the bioavailability of bisphosphonates like intravenous, subcutaneous and intramuscular injections (10-13). Also Asikoglu et al. have demonstrated rectal absorption of ALD (14).

The unique properties like rich blood supply and the large surface area makes vagina an important area for systemic drug delivery (15). The advan-
AFFILIATIONS

1 Ege University, Faculty of

Pharmacy, Department of Radiopharmacy, İzmir, Turkey

2Ege University, Faculty of

Medicine, Department of

Nuclear Medicine, İzmir,

Turkey

${ }^{3}$ Ege University, Faculty of

Pharmacy, Department of

Pharmaceutical Technology,

İzmir, Turkey

CORRESPONDENCE

Derya Illem-Özdemir

E-mail:

deryailem@gmail.com

Received:

12.04.2013

Revision:

28.05.2013

Accepted:

30.05.2013 
tages of vaginally applied dosage forms are avoidance of hepatic first-pass metabolism, decreasing of gastrointestinal and hepatic side effects; possible self-insertion and removal of the dosage form (15-17).

Suppositories generally consist of an active compound loaded into an inert matrix, which may be either a rigid or semi-rigid base. After administration, the role of the suppository is to liberate the active compound, either by melting due to body temperature or by dissolving in the local mucosal fluids, and then to release the active compound to produce a local effect or to move to the mucosal barriers into the systemic circulatory to produce a pharmacological effect (18).

Polyethylene glycol 1500 (PEG) is a water soluble suppository base which is widely used as excipients in a variety of pharmaceutical formulations, such as oral tablets and caplets, solutions and syrups, topical, rectal and vaginal preparations, ophthalmic, dental and parenteral systems $(19,20)$.

Massa estarinum AB (ME) is a synthetic suppository base that consists of a mixture of tri,di- and mono-glycerides of saturated fatty acids. ME has low melting point $\left(29-31^{\circ} \mathrm{C}\right)$. ME is suitable for rapid absorption (19-21).

Vaginal uptake of pharmaceutical dosage forms can be investigated with gamma scintigraphy studies. During the last decades, very important improvements have been achieved in drug development using radiopharmaceuticals as tracers. Suitable radionuclide for scintigraphic studies can be chosen by considering factors such as the radiation energy, half-life, extent of particulate radiation, cost and availability. $99 \mathrm{mTech}-$ netium pertecnetate $(99 \mathrm{mTc})$ is the most popular radionuclide due to its versatile chemistry, near-ideal energy $(140 \mathrm{keV})$, low radiation dose and short half-life $(6 \mathrm{~h})(22,23)$.

The aim of this study is to compare the bone uptake of ALD from ME and PEG suppositories in rabbits. The bone uptake of ALD was observed by gamma scintigraphy studies. For this reason ALD was radiolabeled with $99 \mathrm{~m}$ Tc by direct method. Radiochemical purity and stability of $99 \mathrm{~m}$ Tc-ALD was performed with radiochromatographic studies. ${ }^{99 m T c-A L D ~ c o n-~}$ taining suppositories were prepared with ME and PEG bases. Physical properties of suppositories were evaluated. The physicochemical diffusion study was carried out to compare the permeability of ALD from ME and PEG suppository bases. The $99 \mathrm{mTc}-\mathrm{ALD}$ containing ME and PEG suppositories were administrated to rabbits via vaginal route. The scintigraphic images were obtained with a gamma camera at different time intervals up to five hours.

\section{MATERIALS AND METHODS Materials}

ALD was obtained as a gift from Arylsa Company. ${ }^{99 m T c-s o d i-~}$ um pertechnetate was obtained from Department of Nuclear Medicine of Ege University. Stannous chloride (Sigma) was used as reducing agent and ascorbic acid (Roche) was used as an antioxidant in labeling studies. The solutions were freshly prepared for each experiment under a nitrogen atmosphere. PEG 1500 (Henkel KGaA Düsseldorf, Germany) and ME-AB (Henkel KGaA Düsseldorf, Germany) were used as suppository bases. ALD was pharmaceutical grade and other chemicals used were analytical grade. The Animal Ethics Committee of the Ege University gave approval for the animal experi- ments (Number: B.30.2.EGE.0.01.00.01/04-17/8, 2006). All experiments replicated at least six times. Results are reported as mean \pm standard error.

\section{Radiolabeling Studies}

ALD was directly labeled by $99 \mathrm{mTc}$ with small modification on previously described (14). ALD (5 mg) was dissolved in saline $(0.5 \mathrm{~mL}) .400 \mu \mathrm{g}$ stannous chloride and $1 \mathrm{mg}$ ascorbic acid were added to solution. Radiolabeling was performed with freshly

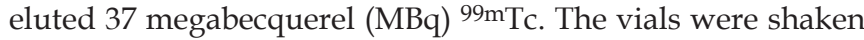
with vortex (Velp Scientifica) at $500 \mathrm{rpm}$ for 30 seconds, filtered through a $0.22 \mu \mathrm{m}$ pore size filter and incubated for 15 $\mathrm{min}$ at room temperature. The radiochemical purity was analyzed by chromatographic studies.

Lyophilized kits were prepared by mixing $5 \mathrm{mg}$ ALD, $400 \mu \mathrm{g}$ stannous chloride and $1 \mathrm{mg}$ ascorbic acid.

\section{Radiochemical Purity and Stability Studies}

Whatman No:3 chromatographic papers were used as stationary phases. Free ${ }^{99 \mathrm{~m} T c}$ was determined by using acetone as the mobile phase. Reduced/Hydrolyzed $(\mathrm{R} / \mathrm{H}){ }^{99 \mathrm{~m} T \mathrm{c}}$ was determined by using saline as mobile phase. \% Radiochemical purity (RP) of 99mTc-ALD was calculated from the following equation (Equation 1) by subtracting from 100 the sum of measured impurities percentages.

\section{Equation 1:}

RP $\%=100-($ Free $99 \mathrm{mTc} \%+\mathrm{R} / \mathrm{H} 99 \mathrm{mTc} \%)$

After labeling ALD with $99 \mathrm{mTc}$, the preparation was left at room temperature for six hours. The labeling stability of the complex was evaluated by radio thin layer chromatography (RTLC) studies for every hour.

\section{Preparation of Suppositories}

Suppositories were prepared by using lyophilized kits which were prescribed above. Kits were labeled with ${ }^{99 \mathrm{~m} T c}$ in saline. The weight deviation of vaginal suppositories was determined previously with inactive experiments and amount of base was

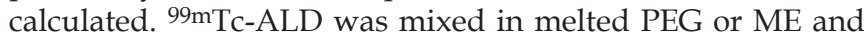
dispersed homogeneously. The resulting mixture was then poured into cylindrical plastic molds and allowed to cool at room temperature. Prepared suppositories were stored at $4{ }^{\circ} \mathrm{C}$ until use. The final value of contents for each suppository was

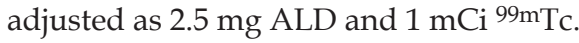

\section{Physicochemical Properties of Suppositories}

The suppositories were analyzed for their weight variation, hardness and melting time. Also 99mTc-ALD loaded suppositories radioactivity was determined in a dose calibrator (Biodex Atomlab 100) to evaluate the drug content homogeneity of suppositories.

\section{Physicochemical Diffusion Test of Suppositories}

The physicochemical diffusion study was carried out to compare the permeability of ALD from different suppository bases (14). For this purpose, $0.5 \mathrm{~g}$ agar was dissolved in $24 \mathrm{~mL}$ water at $100^{\circ} \mathrm{C}$ water bath. After that the mixture was slightly cooled to lower degrees and the indicator (chloramphenicol solution) was added. The holes were opened on the agar with the lower part of hard gelatin capsule (size 4). ${ }^{99 m T c-A L D ~ l o a d e d ~ P E G ~}$ and ME suppositories were placed in the holes and agar plates were incubated in the oven at $37^{\circ} \mathrm{C}$. The diffusion distances were determined by measuring the diameter of the colored 
TABLE 1. Physicochemical properties of PEG and ME suppositories

\begin{tabular}{|c|c|c|c|}
\hline & Weight Variations (g) & Hardness (a) & Melting Time (min) \\
\hline PEG Suppository & $0,112 \pm 0.001$ & $800 \pm 0.000$ & $2.362 \pm 0.005$ \\
\hline ME suppository & $0.098 \pm 0.002$ & $600 \pm 0.000$ & $1.573 \pm 0.003$ \\
\hline
\end{tabular}

zones at different time intervals (0 .5, 1.0, 2.0, 2.5 and $3.0 \mathrm{~h})$. Diffusion distance was calculated by the following equation (Equation 2).

Equation 2:

$\mathrm{X}=(\mathrm{C}-\mathrm{D}) / 2$

$(\mathrm{X}=$ diffusion distance, $\mathrm{C}=$ Zone diameter, $\mathrm{D}=$ Disc diameter $)$

\section{In Vivo Studies}

Female New Zealand White rabbits $(2.5-3.0 \mathrm{~kg})$ were used for animal studies. Experiments with rabbits were performed according to a protocol approved by Animal Ethics Committee of the Ege University.

During the scintigraphy studies rabbits were under anesthetize with Ketamine/Xylazin cocktail. ${ }^{99 m}$ Tc-ALD $(1 \mathrm{mg} / \mathrm{kg})$ loaded PEG and ME suppositories were inserted to the vagina of rabbits under anesthesia. After dosing, the vagina was glued together to prevent a leak of suppository. The scintigraphic images were obtained with a gamma camera (Apex SP-4, Elscint Ltd) equipped with a low-energy high-resolution collimator viewing the whole body of each rabbit in supine position. Serial static images were acquired in a $256 \times 256$ matrix for $300 \mathrm{sec}$. each, at 0, 60, 120, 180, $240 \mathrm{~min}$ after administration of radiolabeled formulations.

\section{Statistical analysis}

The calculation of means and standard deviations were made on Microsoft Excel. Oneway Anova was used to determine statistical significance. Differences at the 95\% confidence level $(\mathrm{p}<0.05)$ were considered significant.

\section{RESULTS AND DISCUSSION}

\section{Radiolabeling Studies}

The radiochemical purity of $99 \mathrm{mTc}$-ALD was found over $99 \%$ at room temperature immediately after incubation time. The complex was found stable at room temperature up to $6 \mathrm{~h}$ without any significant decrease in radiochemical purity $(\mathrm{p}<0.05)$. High radiochemical purity and stability makes $99 \mathrm{mTc}-\mathrm{ALD}$ suitable for investigating bone uptake with gamma scintigraphy.

\section{Physicochemical Properties of Suppositories}

Table 1 shows that all the suppository formulations satisfied the

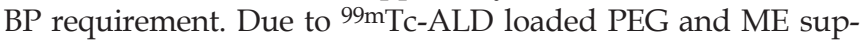
positories were prepared to use for in vivo studies with rabbit, prepared suppositories weight was around $100 \mathrm{mg}$. The average weight of suppositories prepared using PEG and ME were 0.112 and $0.098 \mathrm{~kg}$ respectively. Weight variations recorded were less than $5 \%$. The suppositories prepared by PEG were found to be harder than ME suppositories as compared breaking forces. The hardness of ME suppositories was $600 \mathrm{~g}$ and the suppositories prepared with PEG were harder $(800 \mathrm{~g})$. Melting time for plain suppositories prepared was averagely all less than 30 minutes. Weight variation, hardness and melting time of PEG and ME suppositories are shown in Table 1.
99mTc-ALD loaded suppositories radioactivity was determined in a dose calibrator and study indicated the homogenous drug content

\section{Physicochemical Diffusion Test of Suppositories}

In order to investigate the release of ALD from different suppository bases, two different suppository formulations were prepared by using lipophilic ME and hydrophilic PEG. Diffusion distance of ALD was found significantly different for PEG and ME suppositories $(\mathrm{p}<0.05)$. Diffusion zone of ALD from ME suppositories was $0.620 \pm 0.091 \mathrm{~mm}$ while $10.465 \pm 0.651 \mathrm{~mm}$ diameter zone was observed with PEG suppositories (Table 2).

TABLE 2. The photograph of colored zones and average diffusion distances of 99mTc-ALD from PEG and ME suppositories in chloramphenicol containing agar at 30 and $240 \mathrm{~min}$

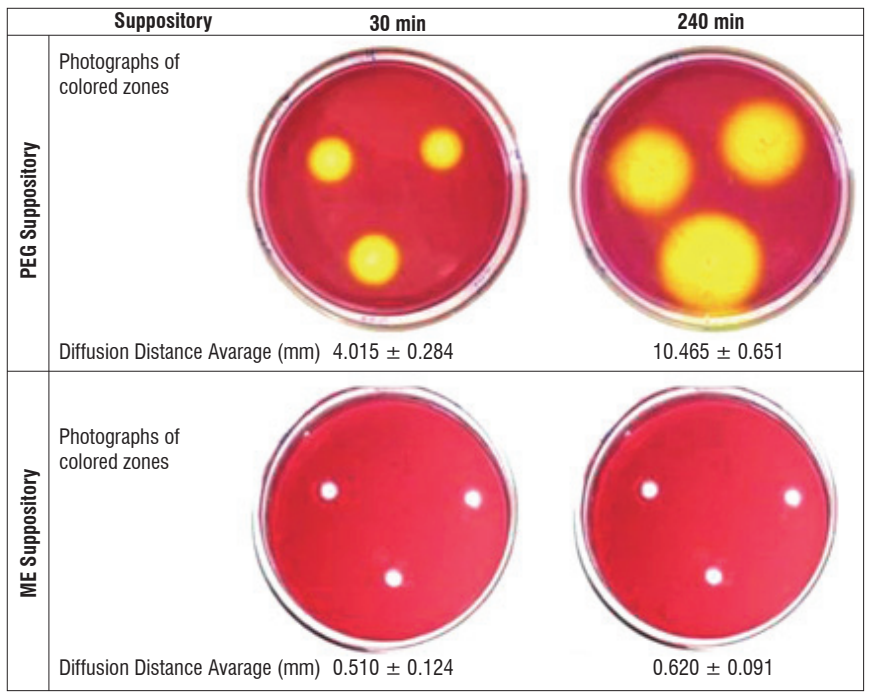

A physicochemical characteristic of a drug is important in selecting the suppository base and in anticipating drug release from that base. Lipophilic drug, in a fatty suppository base has fewer tendencies to escape to the surrounding queues fluids. Thus water-soluble salt are preferred in fatty base suppository but from PEG suppositories, drug release depends on the base dissolving rather than melting so this base can be used for both water-soluble and oil-soluble drugs (18).

PEG is a water soluble polymer that often melts at temperatures higher than the physiological temperature of $37^{\circ} \mathrm{C}$. Consequently, when used in vaginal or rectal formulations, the drug is released gradually, as a result of the progressive dissolution of the PEG excipients in an aqueous dissolution medium. Melting of a fatty base is followed by several successive mechanistic steps, such as spreading of the molten mass, particle dispersion, passage across the interface and finally dissolution of the drug in the hydrophilic fluids (18). 


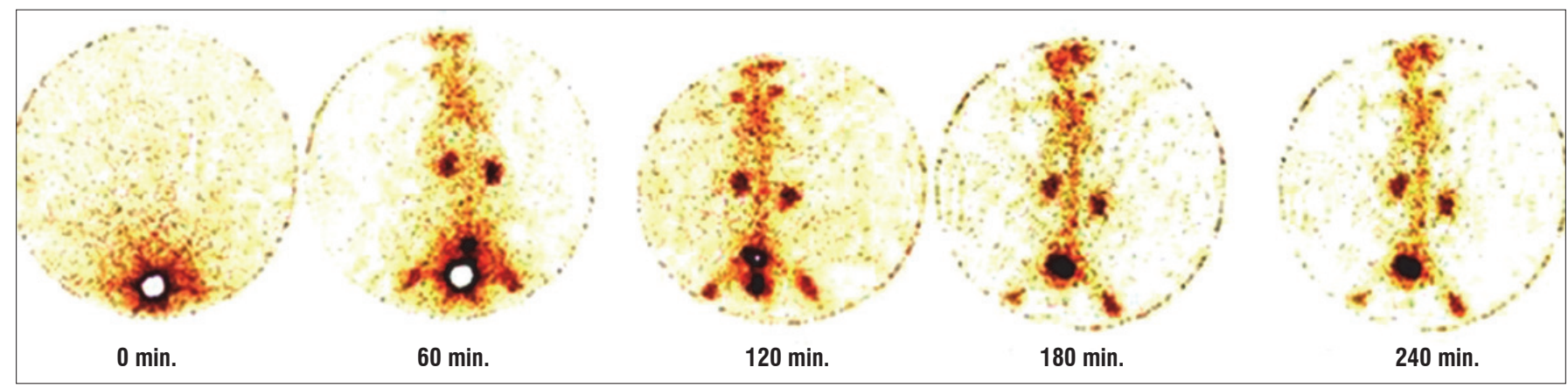

FIGURE 1. Scintigraphic images of 99mTc-ALD suppositories prepared with PEG at 0,60, 120, 180 and 240 min. after administration.

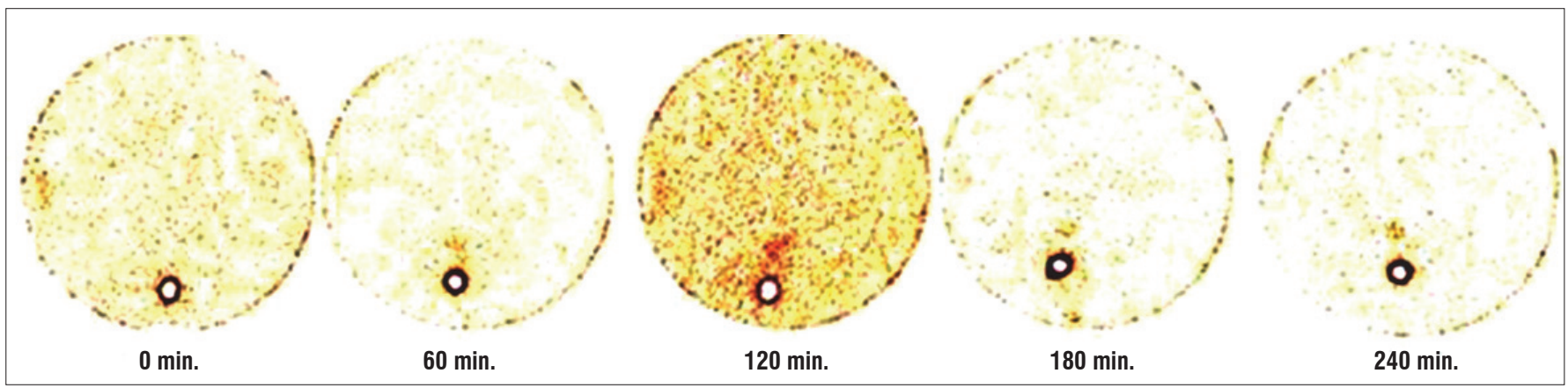

FIGURE 2. Scintigraphic images of 99mTc-ALD suppositories prepared with MEG at 0, 60, 120, 180 and 240 min. after administration.

According to the physicochemical diffusion studies bases play an important role for drug release from suppositories.

\section{In Vivo Studies}

Selection of a suitable base cannot be made in the absence of knowledge of the physicochemical properties and intrinsic thermodynamic activity of the drug substance which is to be incorporated into the suppository. Other drug-related factors can affect the base selection.

The bone uptake of $99 \mathrm{mTc}-\mathrm{ALD}$ following intravaginal administration of PEG and ME suppositories was investigated on static images (Figure 1-2). Scintigraphic images clearly demonstrated the bone uptake of 99mTc-ALD from PEG suppository

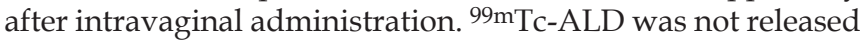
from ME suppository, and the radioactivity stayed in the application point for 240 minute. The differences in the percentage of radioactivity of ME and PEG suppositories remaining in vagina were found significantly different $(P<0.05)$.

Bioavailability depends not only the formulation. The factors which may affect drug release and dissolution, are potential barriers to the passage of dissolved drug into venous blood or lymph also exist in the unstirred water layer, the mucous lay- er, the cellular structure of the mucous membrane and the walls of lymph vessels and blood capillaries.

\section{CONCLUSION}

In this study, $99 \mathrm{mTc}-\mathrm{ALD}$ loaded PEG and ME suppositories were prepared and bone uptake of ALD via vaginal route was estimated by gamma scintigraphy studies. Gamma scintigraphy studies demonstrated the impotence of radiolabeled drugs to investigate the systemic absorption via vaginal application. According to the results of our study, suppository base play major role in drug release and should be selected carefully. With vaginal suppositories of ALD, the undesired side effects, poor gastrointestinal absorption and food interaction can be eliminated. Therefore PEG suppositories of ALD are promising for bone targeting for women.

\section{ACKNOWLEDGMENTS}

This study was supported by Ege University Research Found (08ECZ015). The authors thank to Ege University Nuclear Medicine Department for their technical assistance for the gamma imaging studies. 


\section{Polietilen glikol ve massa estarinum sıvağları kullanılarak hazırlanan vajinal supozituvarlardan salınan alendronat sodyumun kemik tutulumunun karşılaştırmalı incelenmesi}

ÖZET: Çalışmamızın amacı, massa estarinum AB (ME) ve polietilen glikol 1500 (PEG) sıvağları kullanılarak hazırlanan vajinal suppozituvarlardan alendronat sodyumun (ALD) kemik tutulumunun karşılaştırmalı olarak incelenmesidir. Bu amaçla, ALD 99mTeknesyum Perteknetat (99mTc) ile direk metot kullanılarak işaretlenmiş, 99mTC-ALD'ın radyokimyasal saflık ve stabilitesi kromatografik çalışmalar ile incelenmiştir. 99mTc-ALD içeren supozituvarlar ME ve PEG sıvağları kullanılarak hazırlanmış, supozituvarların fiziksel özellikleri incelenmiştir. ALD'ın farklı suppozituvar sıvağlarından salımını karşılaştırmalı olarak incelemek amacı ile fizikokimyasal difüzyon çalışmaları yapılmıştır. 99mTc-ALD'ın kemik tutulumu yapılan gama sintigrafi çalışmaları ile belirlenmiştir. 99mTc-ALD içeren ME ve PEG sıvağları kullanılarak hazırlanan supozituvarlar tavşanlara vajinal yoldan uygulandıktan sonra gama kamera ile $\mathbf{2 4 0}$ dakika boyunca farklı zaman aralıklarında sintigrafik görüntüler alınmıştır. Yapılan çalışmalara göre, 99mTc-ALD'ın radyokimyasal saflığının 6 saat boyunca \%95'in üzerinde olduğu belirlenmiştir. Fizikokimyasal difüzyon çalışmalarında 240 dakika sonunda; ME sıvağı ile hazırlanan supozituvardan salınan ALD $0,620 \pm 0,091 \mathrm{~mm}$ çapta zon oluştururken, PEG ile hazırlanan supozituvardan salınan ALD $10,465 \pm 0,651 \mathrm{~mm}$ çapta zon oluşturmuştur. Yapılan gama sintigrafi çalışmalarına göre, ME sıvağı kullanılarak hazırlanan supozituvarlar uygulanan tavşanlarda herhangi bir kemik tutulumu gözlenmezken, PEG sıvağı kullanılarak hazırlanan supozituvarların uygulandığı tavşanlarda belirgin kemik tutulumu gözlenmiştir. Sonuç olarak fizikokimyasal difüzyon ve gama sintigrafi çalışmalarının sonuçlarının birbirleri ile uyumlu olduğu tespit edilmiştir.

ANAHTAR KELIMELER: Alendronat sodyum, kemik tutulumu, vajinal supozituvar, massa estarinum, polietilen glikol

\section{REFERENCES}

1. Bartl R, Frisch B, Von Tresckow E, Bartl C. Bisphosphonates in Medical Practice. Spriger-Verlag, Heidelberg, Germany. 2007, pp: 35-70.

2. Rolf $W$, Sparidans, Jan den $H$. Chromatographic analysis of bisphosphonates. Pharm World Sci 1999; 21: 1-21.

3. Chaiamnuay S, Saag KG. Postmenopausal osteoporosis. What have we learned since the introduction of bisphosphonates? Rev Endocr Metab Disord 2006; 7: 101-12.

4. Fleisch $H$. Development of bisphosphonates. Breast Cancer Res 2002; 4: 30-4.

5. Ayranov M, Strezov A, Jordanova E, Piperkova E, Sergieva S. Quality control and clinical application of two bone imaging $99 \mathrm{mTc}$ radiopharmaceuticals. J Radio Nucl Chem 1999; 240: 349-52

6. Sambrook PN, Rodriguez JP, Wasnich RD, Luckey MM, Kaur A, Meng L, Lombardi A. Alendronate in the prevention of osteoporosis: 7-year follow-up. Osteoporos Int 2004; 15: 483-8.

7. Biswas $P$, Wilton L, Shakir S. Pharmacovigilance study of alendronate in England. Osteoporos Int 2003; 14: 507-14.

8. Porras AG, Holland SD, Gertz BJ. Pharmacokinetics of alendronate. Clin Pharmacokinet 1999; 36: 315-28.

9. Gertz BJ, Holland, SD, Kline WF, Matuszewski BK, Freeman A, Quan H, Lasseter KC, Mucklow JC, Porras AG. Studies of the oral bioavailability of alendronate. Clin Pharmacol Ther 1995; 58: 288-98.

10. Ezra A, Golomb G. Administration routes and delivery systems of bisphosphonates for the treatment of bone resorption. Adv Drug Deliv Rev 2000; 42: 175-95.

11. Lin JH, Chen IW, deLuna FA, Hichens M. Role of calcium in plasma protein binding and renal handling of alendronate in hypo and hypercalcemic rats. J Pharmacol Exp Ther 1993; 267: 670-5.

12. Lin JH, Chen IW, Duggan DE. Effects of dose, sex, and age on the disposition of alendronate, a potent antiosteolytic bisphosphonate in rats. Drug Metab Dispos 1992; 20: 473-8.
13. Rossini M, Braga V, Gatti $D$, Gerardi $D$, Zamberlan $N$, Adami S. Intramuscularclodronate therapy in postmenopausal osteoporosis. Bone 1999; 24: 125-9.

14. Asikoğlu M, Ozguney I, Ozcan I, Orumlu O, Guneri T, Koseoğlu K, Ozkilic H. The absorption of $(99 \mathrm{~m}) \mathrm{Tc}-$ alendronate given by rectal route in rabbits. Pharm Dev Technol 2008; 13: 213-20.

15. Valenta $C$. The use of mucoadhesive polymers in vaginal delivery. Adv Drug Deliv Rev 2005; 57: 1692-712.

16. Arici M, Güneri T, Ertan G. Preparation and diffusional evaluation of sustained-release suppositories containing ibuprofen microspheres. FABAD J Pharm Sci 2004; 29: 177-84.

17. Özgüney (Sarigüllü) I, Özcan I, Ertan G, Güneri T. The Preparation and Evaluation of Sustained Release Suppositories Containing Ketoprofen and Eudragit RL 100 by Using Factorial Design. Pharm Dev Technol 2007; 12: 97-107.

18. Thawatchai $P$, Parichart $C$, Tharatree $S$, Chirayu S. Role of Xanthan Gum on Propranolol HCl Release from Single and Double Layered Suppositories. RJPBCS 2013; 4: 1034-44.

19. Henry C. The Advantages of Using Suppositories, Nursing Times 1999; 95: 50-41

20. Kellaway IW, Marriott C. Correlations between physical and drug release characteristics of polyethylene glycol suppositories. J Pharm Sci 1975; 64: 1162-6

21. Gjellan $K$, Graffner $C$, Quiding $H$. İnfluence of Amount of Hard Fat in Suppositories on The İn Vitro Release Rate and Bioavailability of Paracetamol and Codeine. Int J Pharm 1994; 102: 71-80

22. Krishnaiah $Y S$, Satyanarayana $S$, Rama Prasad $Y V$, Narasimha Rao S. Gamma scintigraphic studies on guar gum matrix tablets for colonic drug delivery in healthy human volunteers. J Control Release 1998; 13; 55: 245-52.

23. Marvola $T$, Marvola $J$, Kanerva $H$, Ahonen $A$, Lindevall K, Marvola M. Neutron activation based gamma scintigraphic evaluation of enteric-coated capsules forlocal treatment in colon. Int J Pharm. 2008; 2; 349: 24-9. 